\title{
EXPLORATION AND UTILIZATION OF LOCAL BIODIVERSITY WITH THE POTENTIAL FOR EMPOWERMENT OF CONSERVATION VILLAGE MODELS FATUSENE VILLAGE, NORTH CENTRAL TIMOR SUBDISTRICT
}

\author{
REMIGIUS BINSASI*) AND POLIKARPIA WILHELMINA BANI \\ Program Studi Biologi, Fakultas Pertanian, Universitas Timor, Jalan Km. 09, Kefamenanu, Nusa Tenggara Timur, \\ Indonesia 85616
}

*Email: binsasiremigius@gmail.com

Accepted Juny 07, 2021 / Approved September 01, 2021

\begin{abstract}
Biodiversity is a strategic resource and plays a role in determining the quality of human life. This study aimed to determine the types of vegetation that were used and developed for the empowerment of conservation village model, know the local potential that could be empowered to develop conservation village models, analyze community empowerment activities related to the use of local biodiversity, and analyze factors related to the utilization of local biodiversity that had the potential to empower the people of Fatusene Village. The techniques used in data collection were survey, interview, and documentation. The approach used was qualitative and quantitative descriptive. The results showed that there were 17 tree species from 11 families found in several springs in the Fatusene Village area. The plant species that had the highest and lowest importance value index were Zyzygium aqueum and Leucaena leucocephala with an importance Value Index of 47.28\% and 5.45\%, respectively. The distribution of plant species was not evenly distributed at each spring point, indicating the influence of abiotic environmental factors and human activities that greatly affected the existence of plants in terms of conservation. Local potentials that could be empowered and utilized to develop a conservation village model in the Fatusene Village area were agriculture and plantations, livestock, and forestry. The community empowerment activities in Fatusene Village are usually held before the implementation of activities within one year to discuss village community empowerment programs and other unexpected events such as crop failure, problems with clean water, environmental sanitation and other physical developments. To support this activity, it is carried out reforestation around the springs, reducing tree exploitation which is one of the contributions to water availability, protecting and preserving springs as a source of life for the people of Fatusene Village, East Miomaffo District, North Central Timor Regency.
\end{abstract}

Key words: Conservation Village Model, Exploration, Fatusene Local Biodiversity

\section{INTRODUCTION}

Biodiversity is a strategic resource and plays a role in determining the quality of human life. Utilization that is not environmentally safe has caused higher rate of degradation, so that it threatens biodiversity globally. (Butchart et al., 2010; Houdet et al., 2012). One of the impacts is flora biodiversity crisis leading to environmental crisis, social crisis, food crisis, water and energy crisis, and it eventually causes political, social, and economic issues for international society (Dasgupta and Beard, 2008, Lele et al., 2010). Several springs in Fatusene Village, East Miomaffo Subdistrict, North Cental Timor District are often confronted by drought problem during the dry season. One of the potentials supporting the availability and contribution to springs is exploration and identification on vegetation around the springs.

The main issue in conservation is preventing extinction, which can be happened to biodiversity at all levels of ecosystem, species, as well as genetic aspects. Extinction, especially mass extinction must be prevented by implementing broad conservation and sustainable management. Conservation area is functioned to keep the ecosystem in balance, preserve biodiversity and meet the needs of people living around the area (Sepriyanto, 2012).

Community empowerment essentially is a society-centered development concept to promote and improve creative innovation of the people in handling problems and developing its excellent potentials in a sustainable manner through society improvement in order to implement the development results to be better and sustainably. Sepriyanto (2012) also argued that community empowerment is an effort to increase the welfare of people living around the forest area and to improve their dignity reasonably so that they can live independently in the conservation area.

Conservation Village Model (MDK) is intended as an effort to protect and preserve conservation areas by involving the community participation through the increase in and development of conservation awareness. This aims to create a harmonious relationship between the preservation of the area and the needs of the community around the area (Suroso, 2015). MDK is expected to create and increase community capacity, reduce dependency on the area, and provide positive impacts on the protection, preservation and utilization of conservation areas. In the long term, it is intended that the conservation area will remain sustainable and the community welfare will be fulfilled. Community empowerment is also an approach to improve people's ability and live through participation and opportunities provided for the community in a development program.

This research was begun with exploration, inventory and identification of local biodiversity and the potentials developed in Fatusene Village, North 
Central Timor Regency. As Fatusene Village is determined as a Conservation Village Model, it is expected that this village can be a role model for other villages in developing various activities related to community empowerment in conservation, social, economic and cultural aspects. According to Widjajanti (2011), the empowerment process is marked by the community's ability to make problem analysis, planning, implementation and evaluation of village empowerment programs.

Fatusene Village is located in East Miomaffo District within the circle of North Central Timor Sub district. It has a high flora biodiversity and local potentials that have not been developed maximally. Therefore, it is essential to allow development using conservation village model based on local potentials empowerment with an expectation that Fatusene village can be prosperous in the future (Fatusene Village Profile, 2019)

This research was conducted to (1) determine the types of vegetation that can be utilized and developed for the development of conservation village model; (2) identify local potentials that can be empowered to develop conservation village model; (3) analyze community empowerment activities related to the utilization of local biodiversity of MDK in Fatusene Village; (4) analyze the factors related to the potential utilization of local biodiversity for MDK empowerment in Fatusene Village, North Central Timor Sub district.
The results of this research can be used as information for Fatusene Village community about the significance of the types of vegetation found around the springs. Therefore, these vegetations need to be preserved, protected and conserved, without conducting illegal exploitation, so it would not affect the water discharge during the dry season. In addition, it is necessary to conserve plants with diversity values for the sustainability of the springs.

\section{RESEARCH METHOD}

This research was conducted from May to October 2020 in Fatusene Village, East Miomaffo District, North Central Timor Sib District, East Nusa Tenggara Province using a qualitative and quantitative descriptive approach to determine the types of vegetation, local potentials, implementation of community empowerment programs, and factors affecting the development of Fatusene Village as a Conservation Village Model.

Data collected in this research were primary and secondary data. The primary data were collected directly at the research location related to local potentials that were developed to support community empowerment activities in the Fatusene Village area including the potentials for agriculture, plantation, livestock, forestry and clean water sources (Fatusene Village Profile, 2019).

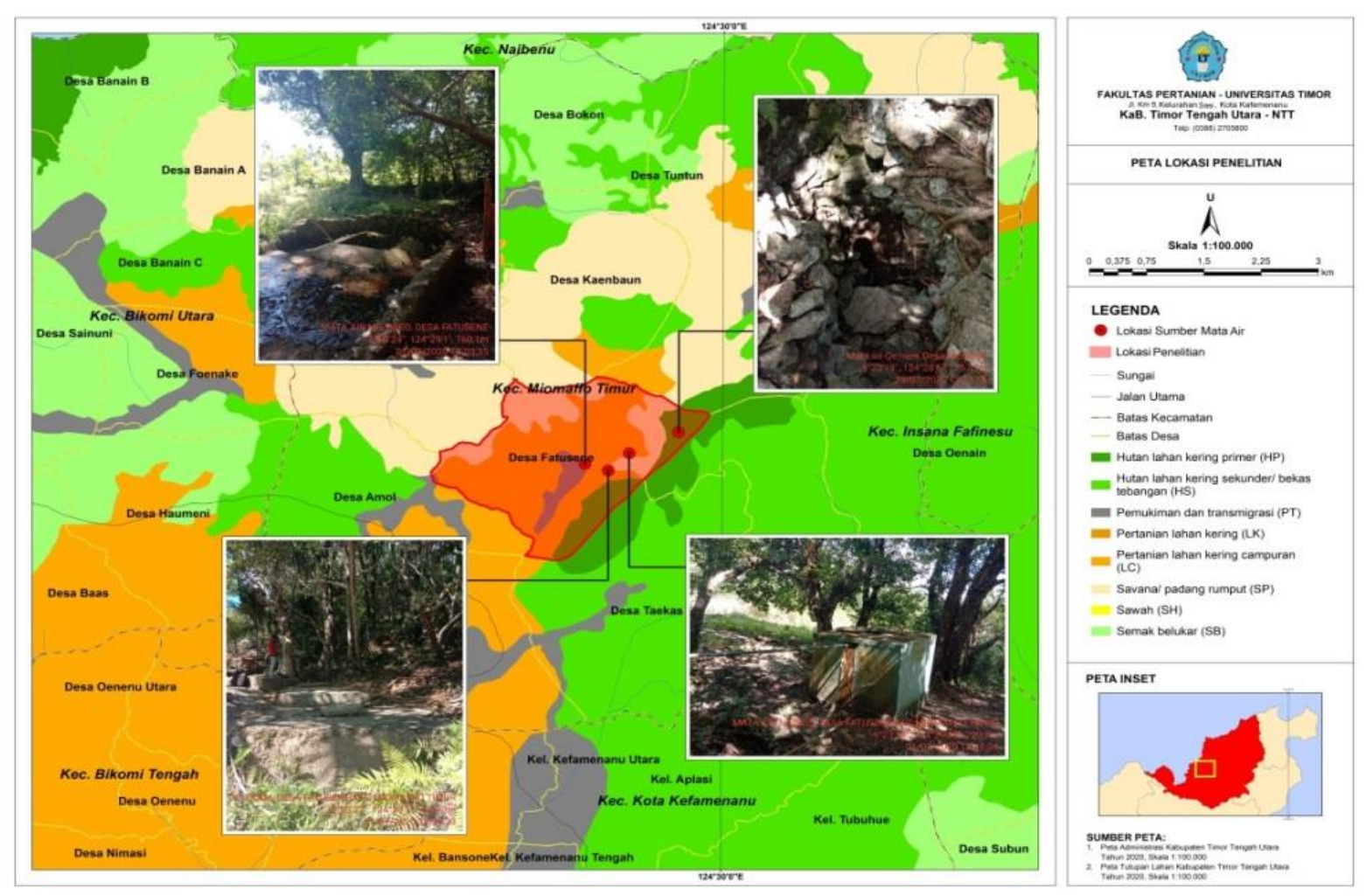

Figure 1 Research location, Fatusene Village, East Miomaffo District 
The secondary data was obtained through document study from several sources including: planning documents, activity reports, statistics and other types of documents regarding community empowerment activities in Fatusene Village, TTU Sub district to complement the primary data. Data collection was carried out by conducting survey to describe in general the research location, by conducting interviews with village heads and community leaders regarding community empowerment programs in the current year, local potentials developed to support the Fatusene village community empowerment program, and the last by documentation. Respondents for community leaders were selected through purposive sampling. Vegetation observation in the field was performed to find the importance value index by analyzing tree vegetation by using the quadratic plot method as many as 4 plots of $20 \mathrm{~m} \times 20 \mathrm{~m}$. The importance value index of a species ranges from $0 \%-300 \%$. It provides an overview or the role of a plant species in the community. The tools used in this research were GPS, to determine the coordinates and altitude; Med line, to measure the circumference of the rod; Camera, to document research activities; and Stationery to record the results of the research.

Data and information from the community on flora biodiversity were analyzed using descriptivequalitative and quantitative methods, while flora biodiversity conservation data were analyzed using descriptive-qualitative and quantitative methods by calculating the density, frequency, basal area and importance value index (IVI), and referring to the vegetation formula below (Sancayaningsih et al., 2014) Absolute density

$$
\mathrm{DM}=\frac{\text { Number of individuals }}{\text { Total area sampled }}
$$

Relative density

$$
\mathrm{DR}=\frac{\text { Spesies A density }}{\text { Total density of all species }} \times 100 \%
$$

Frequency

$$
\mathrm{F}=\frac{\text { Area of plots in which a species occurs }}{\text { Total area sampled }}
$$

Relative frequency

$$
\mathrm{FR}=\frac{\text { frequency of species A }}{\text { Total frequency of all species }} \times 100 \%
$$

Basal area

$$
\text { Lba }=1 / 4 \times \pi \times \text { diameter }^{2}
$$

Basal area

$$
\begin{aligned}
& \text { LbaR }=\frac{\text { basal area species } \mathrm{A}}{\text { total lba of all species }} \times 100 \% \\
& \text { Important value } \\
& \mathrm{NP}=\mathrm{DR}+\mathrm{FR}+\mathrm{LBAR}
\end{aligned}
$$

\section{RESULT AND DISCUSSION}

The results of the research showed that Fatusene Village in general was a highland area with an altitude of 784 meters above sea level and its natural landscape consisted of valleys and hills area with an average rainfall of $1,164 \mathrm{~mm} /$ year. Besides, the number of rainy months was found to be 5 months, while the average daily temperature was $24,30{ }^{\circ} \mathrm{C}$.

The topography of Fatusene Village was hilly with the plains spread sporadically in a narrow cluster flanked by highlands or hills. The land with a slope of $15-40 \%$ reached $38.07 \%$ and the land with a slope of more than $40 \%$ reached $35.46 \%$. This geomorphological condition caused agricultural activities to be very limited to dryland farming. Dryland farming was mostly done in areas with steep slopes so that productivity was low (Fatusene Village Profile, 2019)

\section{Flora vegetation biodiversity}

Vegetation around springs plays a role in maintaining the sustainability of the flow of the springs and the availability of water in the area (Trimanto, 2013). Vegetation functions as a hydrological regulator and also overcomes drought (Indriyanto, 2008). The types of vegetation found in several springs are shown in table 1 below:

The results showed that at least 17 tree species from 11 families were found around Oe'ekam, Nefo beo, Nainus, and Oe'naek springs in Fatusene Village area, East Miomaffo District. Of the 11 families, the Fabaceae family was found to be dominating with the species of Dalbergia latifolia, Acacia mangium, Pterocarpus indicus, Vachellia leucophloea, and Leucaena leucocephala; then it was followed by Arecaceae and Moraceae families with two species Areca catechu, Cocos nucifera, Ficus benjamina and Artocarpus heterophyllus, respectively. Meanwhile, other families only had one species each. At the observation location, Moraceae and Myrtaceae families had species with a quite large trunk diameter reaching 2 meters. The highest dominance and frequency belonged to Myrtaceae family with an average encounter frequency of $>75$. Banyan and rose apple trees were found in all observed springs. This indicates that these plants are very adaptive to the surrounding environmental conditions. Of the 17 species, three of them are trees that are intentionally planted as wood producers, namely teak, mahogany, and coconut; In addition, areca nut and oranges are local potential plants of Fatusene Village which are used for traditional needs, treats for guests and are also marketed to meet the needs of the local people.

Plant species having the highest and lowest importance value indexes were Zyzygium aqueum and Leocaena lecocephala with $47.25 \%$ and $5.45 \%$, respectively. The plant species was not evenly distributed at each point of the spring. It shows that abiotic environmental factors and human activities greatly affect the existence of plants in terms of preservation. It can be shown in the diagram below.

The composition of vegetation around the springs includes herbs, shrubs, lianas and trees. The vegetation is dominated by big trees. The vegetation condition at the four springs is still dense. The species with the highest number of individuals for Oe'ekam spring is 
dominated by Syzygium aqueum from the Myrtaceae family; for the Nefo beo spring, it is more dominated by the Ficus group from the family of Moraceae Ficus elastica, Ficus benjamina, and Ficus annulata; Banyan tree species and big tree types with strong roots are often found around the springs (Agustina and Arisoesiloningsih, 2013; Trimanto, 2013). The diameter of the trees from Ficus genus found around the springs is quite large compared to other trees, which is above $50 \mathrm{~cm}$. In the spring area, this tree grows very close to the edge of the spring, and its roots often lay in the water. For Nainus spring, that is more dominant species with the highest number of individuals is Syzygium aqueum species from the Myrtaceae family; while Oe'naek spring were dominated by species with the highest number of individuals from the species Swietania macrophylla King from the Meliaceae family.

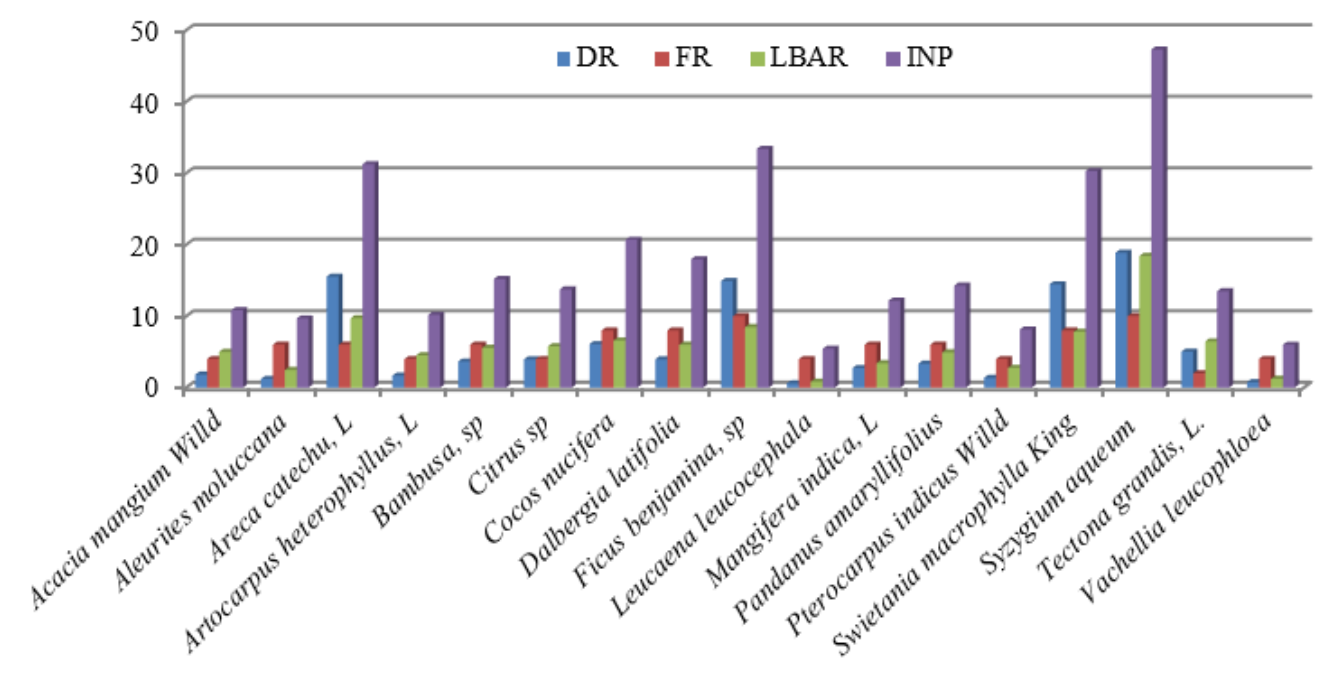

Figure 2 Calculation of Importance Value Index of vegetation-composing species in the spring area of Fatusene Village, North Central Timor Sub District
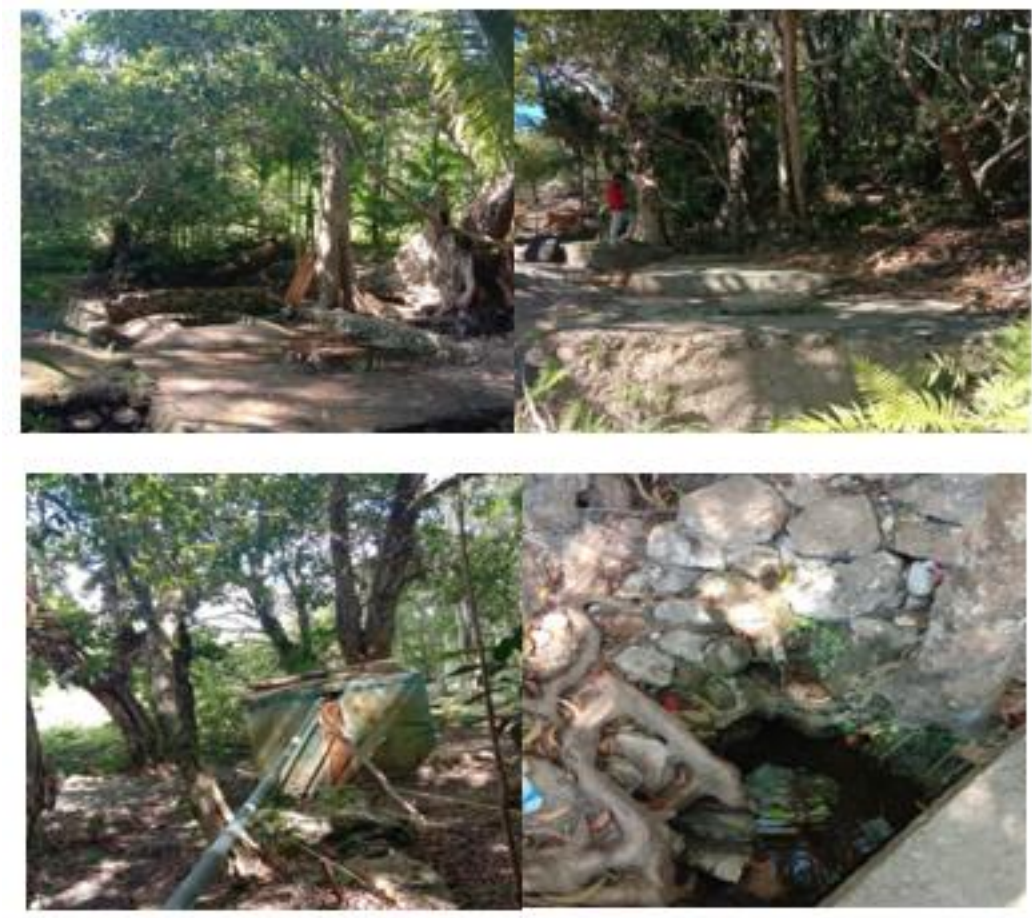

Figure 3 Vegetation conditions in Nefobeo spring, Oe'ekam spring, Nainus spring, and Oe'naek spring 
Table 1 Plant species in several springs in Fatusene Village.

\begin{tabular}{|c|c|c|c|c|c|c|c|c|c|c|c|c|}
\hline No & Species & $\begin{array}{l}\text { Indonesian } \\
\text { Name }\end{array}$ & $\begin{array}{l}\text { Local } \\
\text { Name }\end{array}$ & Family & $\begin{array}{l}\text { Total } \\
\text { Indiv }\end{array}$ & Density & $\begin{array}{l}\text { Relative } \\
\text { Density }\end{array}$ & Freq & $\begin{array}{c}\text { Relative } \\
\text { Freq } \\
\end{array}$ & LBA & LBAR & IVI \\
\hline & & & & & & (Di) & (Rdi) & $(\mathrm{Fi})$ & (Rfi) & & & \\
\hline 1 & Acacia mangium Willd & Akasia & Hau bese & Fabaceae & 12 & 0.03 & 1.826 & 0.4 & 4 & 745.486 & 5.0035 & 10.830 \\
\hline 2 & Aleurites moluccana & Kemiri & Feno & Euphorbiaceae & 8 & 0.02 & 1.218 & 0.6 & 6 & 367.946 & 2.4696 & 9.687 \\
\hline 3 & Areca catechu, L & Pinang & Puah & Arecaceae & 102 & 0.255 & 15.525 & 0.6 & 6 & 1447.342 & 9.7142 & 31.239 \\
\hline 4 & Artocarpus heterophyllus, L & Nangka & Jak & Moraceae & 11 & 0.0275 & 1.674 & 0.4 & 4 & 673.454 & 4.5200 & 10.194 \\
\hline 5 & Bambusa, sp & Bambu & $\mathrm{Ob} /$ peto & Poaceae & 24 & 0.06 & 3.653 & 0.6 & 6 & 828.135 & 5.5582 & 15.211 \\
\hline 6 & Citrus sp & Jeruk & Lelo & Rutaceae & 26 & 0.065 & 3.957 & 0.4 & 4 & 861.093 & 5.7794 & 13.737 \\
\hline 7 & Cocos nucifera & Kelapa & Noah & Arecaceae & 40 & 0.1 & 6.088 & 0.8 & 8 & 982.034 & 6.5912 & 20.679 \\
\hline 8 & Dalbergia latifolia & Sonokeling & & Fabaceae & 26 & 0.065 & 3.957 & 0.8 & 8 & 894.163 & 6.0014 & 17.959 \\
\hline 9 & Ficus benjamina, sp & Beringin & Nunuh & Moraceae & 98 & 0.245 & 14.916 & 1 & 10 & 1263.546 & 8.4806 & 33.397 \\
\hline 10 & Leucaena leucocephala & & Angkai & Fabaceae & 4 & 0.01 & 0.609 & 0.4 & 4 & 125.541 & 0.8426 & 5.451 \\
\hline 11 & Mangifera indica, $\mathrm{L}$ & Mangga & Upun & Anacardiaceae & 18 & 0.045 & 2.740 & 0.6 & 6 & 509.245 & 3.4179 & 12.158 \\
\hline 12 & Pandanus amaryllifolius & Pandan & Pandan & Pandanaceae & 22 & 0.055 & 3.349 & 0.6 & 6 & 733.601 & 4.9237 & 14.272 \\
\hline 13 & Pterocarpus indicus Willd & Kayu merah & Matani & Fabaceae & 9 & 0.0225 & 1.370 & 0.4 & 4 & 412.38 & 2.7678 & 8.138 \\
\hline 14 & Swietania macrophylla King & Mahoni & Mahoni & Meliaceae & 95 & 0.2375 & 14.460 & 0.8 & 8 & 1165.379 & 7.8217 & 30.281 \\
\hline 15 & Syzygium aqueum & Jambu air & Hau oben & Myrtaceae & 124 & 0.31 & 18.874 & 1 & 10 & 2743.395 & 18.4130 & 47.287 \\
\hline 16 & Tectona grandis, $\mathrm{L}$. & Jati & Jati & Lamiaceae & 33 & 0.0825 & 5.023 & 0.2 & 2 & 963.237 & 6.4650 & 13.488 \\
\hline \multirow[t]{2}{*}{17} & Vachellia leucophloea & Kabesak & Besak & Fabaceae & 5 & 0.0125 & 0.761 & 0.4 & 4 & 183.284 & 1.2302 & 5.991 \\
\hline & & & & & & 1.643 & 100 & 10 & 100 & 14899.26 & 100 & 300 \\
\hline
\end{tabular}




\section{Local potentials developed in Fatusene Village area}

Local potentials that can be explored and utilized to develop a conservation village model in Fatusene Village area were agriculture, plantation, animal husbandry, forestry and clean water sources. From its natural conditions, the natural resources owned by Fatusene Village and its development potentials can be identified. The identification results of natural resources in Fatusene Village, East Miomaffo District can be seen in Table 1 below (Fatusene Village Profile, 2019).

Table 2 shows that the natural resources developed in Fatusene village were agriculture, plantation, farm, forestry and clean water sources. The types of flora that were developed from each natural resource have positive values that continue to be developed for the development of conservation village model. The production of natural resources yielded in the first year and subsequent years was greatly increasing. It shows that community involvement in cultivating the land as a source of production to support people's lives in general was very high.

The distinctive and unique local potentials of Fatusene Village that continue to be developed for community lives are areca nut and oranges. These two types of local potential are species that are always used for traditional needs, treats for guests, invitees and are also marketed to meet the needs of the community.

Table 2. Local potentials developed in Fatusene Village area

\begin{tabular}{|c|c|c|c|c|}
\hline \multirow[t]{2}{*}{ No } & \multirow[t]{2}{*}{ Natural Resources } & \multicolumn{3}{|c|}{ Annual Production } \\
\hline & & Unit & Year n -2 & Year $\mathbf{n}-1$ \\
\hline \multirow[t]{18}{*}{1} & Agriculture & & & \\
\hline & a. Crops & & & \\
\hline & - Corn & $\mathrm{Kg} /$ Year & 8000 & 8.437 \\
\hline & - Rice & $\mathrm{Kg} /$ Year & 5000 & 5.357 \\
\hline & - Cassava & Ton/Year & 2,5 & 37.252 \\
\hline & - Tubers & $\mathrm{Kg}$ & 150 & - \\
\hline & - Vegetable & $\mathrm{Kg}$ & 400 & \\
\hline & b. Fruits & & & \\
\hline & - Mango & $\mathrm{Kg} /$ tree/yr & $2000 / 250$ & $242 / 1.185$ \\
\hline & - Orange & $\mathrm{Kg} /$ tree/yr & $2000 / 216$ & $2500 / 647$ \\
\hline & - Pineapple & $\mathrm{Kg} /$ tree/yr & $5000 / 5000$ & $5000 / 5000$ \\
\hline & c. Herbs & & & \\
\hline & - Turmeric & $\mathrm{Kg}$ /Are & $900 / 100$ & $1000 / 200$ \\
\hline & - Ginger & $\mathrm{Kg} / \mathrm{Are}$ & $700 / 30$ & $1000 / 200$ \\
\hline & - Galangal & $\mathrm{Kg}$ /Are & $50 / 2$ & $75 / 3,6$ \\
\hline & - Betel leaves & $\mathrm{Kg}$ /Are & $20 / 180$ & $500 / 50$ \\
\hline & - Lemongrass leaves & Cluster & 128 & 128 \\
\hline & - Cat's whiskers & Tree & 10 & 10 \\
\hline \multirow[t]{4}{*}{2} & Plantation & & & \\
\hline & - Coconut & Piece/Tree/Yr & $5000 / 100$ & $5200 / 366$ \\
\hline & - Areca nut & $\mathrm{Kg} / \mathrm{Tree} / \mathrm{Yr}$ & $300 / 100$ & $250 / 75$ \\
\hline & - Candle nut & $\mathrm{Ha} / \mathrm{Tree} / \mathrm{Yr}$ & $5 / 150$ & $5 / 200$ \\
\hline \multirow[t]{10}{*}{3} & Animal husbandry & & & \\
\hline & a. Types of livestock & & & \\
\hline & - Cow & Head & 116 & 116 \\
\hline & - Pig & Head & 128 & 130 \\
\hline & - Goat & Head & 37 & 82 \\
\hline & - Organic chicken & Head & 506 & 369 \\
\hline & - Dog & Head & 131 & 102 \\
\hline & b. Availability of animal feed & & & \\
\hline & - Feed plant area & $\mathrm{Ha}$ & 8 & 10 \\
\hline & - Forage production & Ton/ha & 4 & 6 \\
\hline \multirow[t]{4}{*}{4} & Forestry & & & \\
\hline & - Teak & Tree & 100 & 123 \\
\hline & - Mahogany & Tree & 100 & 125 \\
\hline & - Sandalwood & Tree & 25 & 25 \\
\hline \multirow[t]{3}{*}{5} & Clean water source & & & \\
\hline & - Spring & Unit & 3 & 3 \\
\hline & - Water reservoir / Embung & Unit & - & - \\
\hline
\end{tabular}




\section{Forms and efforts of community empowerment to utilize local biodiversity}

The results of the interview with the Head of Fatusene Village indicated that to improve the community empowerment program in Fatusene Village, it is important to perform deliberation before the implementation of activities in one current year. The deliberation was firstly held at the sub-village level. The results of the sub-village level deliberation would be a reference for plenary and discussion at the village development planning deliberation stage at the Fatusene Village level, East Miomaffo District, North Central Timor Sub district. The implementation of Musdus (sub village deliberation) and Musrenbangdes (village development planning deliberation) at the Fatusene Village level are carried out once a year. In addition to these two activities, there are two other village deliberation that are usually held. Other village deliberation activities aim to discuss unexpected events such as crop failure, clean water problems, environmental sanitation and other physical development.

Village deliberation activities and community empowerment at the Fatusene Village level are also in the form of collaboration between the Fatusene Village Administrative and Non-Governmental Organizations or certain assistance groups. This collaboration aims to develop local potentials in handicrafts such as yarn dyeing, tie weaving, Artificial Insemination (AI) trainings which are also a feature product at the Fatusene Village level directly facilitated by Livestock Service Office at the North Central Timor Sub District and Livestock Service Office of East Nusa Tenggara Province to support sustainable community empowerment activities.

Biodiversity utilization carried out by the Fatusene Village to support community empowerment programs are utilizing the distinct and unique local potentials of Fatusene Village that continue to be developed for community lives, namely areca nut and oranges. These two types of local potential are types of plants that are frequently used for traditional ceremonies, treats for guests, invitees and are also marketed to meet the needs of the community. The effort of community empowerment is by planting the local plant every year in order to maintain, protect and preserve the environment.

\section{Factors Supporting Utilization of Local Biodiversity For Community Empowerment}

The factors supporting the utilization of local biodiversity for community empowerment in Fatusene Village are vegetation, water and public awareness. Community empowerment around the spring area is one of the government's efforts to increase awareness on natural resources in order to maintain the balance of water availability to meet the needs of living (Suroso, 2015). Water resource management according to Aulia and Dharmawan (2010) must be adapted to local conditions in each region because each region has their own characteristics.
Spring management and preservation aims at increasing public awareness of the importance of spring conservation which is manifested by reforestation around the springs, reducing tree exploitation as a contribution to water availability, maintaining and preserving springs as a source of life for the community in Fatusene Village, East Miomaffo District, North Central Timor Sub District.

\section{CONCLUSION}

Local biodiversity that can be explored and utilized to develop the Conservation Village Model in the Fatusene Village area, North Central Timor Sub District, includes agriculture, plantation, animal husbandry, forestry and clean water sources. These local potentials have a close relationship between vegetation and the environment to empower the community by utilizing 17 plant species of 11 families to develop water conservation. Plant species which have an importance value index and evenly distributed frequency at each spring point are Syzygium aqueum with an IVI of 47.28\%; and Ficus benjamina, sp with an IVI of $33.39 \%$. Other supporting factors of the community empowerment program are village deliberation after the deliberation at sub-village level and Musrembangdes deliberation which is held once in a year to discuss unexpected events such as crop failure, clean water problems, environmental sanitation and other physical developments. The activity of spring conservation aims at increasing public awareness of the importance of springs which is manifested by reforestation around the springs, reducing tree exploitation as one of the contributions to the availability of springs, maintaining and preserving springs as a source of life for the people of Fatusene Village.

\section{REFERENCES}

Agustina L, Arisoesiloningsih E. 2013. Variasi profil vegetasi pohon riparian di sekitar mata air dan saluran irigasi tersier di Kabupaten Malang. Jurnal Biotropika 1 (3) : 85-89

Aulia TOS, Dharmawan AH. 2010. Kearifan lokal dalam pengelolaan sumberdaya air di Kampung Kuta. Sodality: Jurnal Transdisiplin Sosiologi, Komunikasi, dan Ekologi Manusia. 4 (3): 345355.

Butchart, S.H., Walpole, M., Collen, B., van-Strien, A., Scharlemann, J. P., Almond, R. E., Baillie, J. E., Bomhard, B., Brown, C., Bruno, J., Carpenter, K. E., Carr, G. M., Chanson,J., Chenery, A. M., Csirke, J., Davidson, N. C., Dentener, F., Foster, M., Galli, A., Galloway, J.N., Genovesi, P., Gregory, R.D., Hockings, M., Kapos, V., Lamarque, J.F., Leverington, F., Loh, J., McGeoch, M.A., McRae, L., Minasyan, A., Hernandez, Morcillo, M., Oldfield, T.E., Pauly, D., Quader, S., Revenga, C., Sauer, J.R., Skolnik, 
B., Spear, D., StanwellSmith, D., Stuart, S.N., Symes, A., Tierney, M., Tyrrell, T.D., Vie, J.C., Watson, R. (2010). Global Biodiversity: Indicators of Recent Declines. Science, 328, 1164-1168.

Dasgupta, A., Beard, V.A. (2008). Community Drive Development, Collective Action and Elite Capture in Indonesia. Development Change, 38(2), 229249.

Houdet, J., Trommetter, M., Weber, J. (2012). Understanding Changes in Business Strategies Regarding Biodiversity and Ecosystem Services. Ecological Economics, 73, 37-46.

Indriyanto. 2008. Ekologi Hutan. Jakarta: PT Bumi Aksara.

Lele, S., Wilshusen, P., Brockington, D., Seidler, R., Bawa, K. (2010). Beyond Exclusion: Alternative Approaches to Biodiversity Conservation in the Developing Tropics. Current Opinion Environment Sustainability, 2, 1-7.

Profil Desa Fatusene, 2019. Kecamatan Miomaffo Timur Kabupaten Timor Tengah Utara Propinsi Nusa Tenggara Timur
Sancayaningsih, R. P., Saputra, A. and Fatimatuzzahra. 2014. Tree Vegetation Analysis of Catchment Areas in Various Springs. Proceding. The $4^{\text {th }}$ Annual Basic Science International Conference (BaSIC) in conjunction with The $5^{\text {th }}$ International Conference on Global Conservation (ICGRC)2014. UB, February 12-13 2014.

Sepriyanto Y.D. (2012). Pemberdayaan Masyarakat Di Sekitar Balai Taman Nasional Gunung Palung Kecamatan Sukadana Kabupaten Kayong Selatan (Studi Kasus Desa Gunung Sembilang). Jurnal Tesis-PMIS UNTAN.

Suroso, S.P. 2015. Penyelamatan sumber mata air bagi kehidupan. Penyuluh kehutanan Dinas kehutanan dan perkebunan. DIY

Trimanto.2013. Diversitas pohon sekitar aliran mata air di Kawasan Pulau Moyo Nusa Tenggara Barat. Prosiding Seminar Nasional X Pendidikan Biologi FKIP UNS Surakarta.

Widjajanti K. 2011. Model pemberdayaan masyarakat. Jurnal Ekonomi Pembangunan. 12(1): 15-27. 